\title{
Eyelid Metastasis as the Initial Presentation of a Renal Cell Carcinoma: a Case Report and Review of the Literature.
}

\section{QiXiang Fang}

Xi'an Jiaotong University Medical College First Affiliated Hospital

\section{Na Xie}

Xi'an Jiaotong University Medical College First Affiliated Hospital

\section{Wei Chen}

Xi'an Jiaotong University Medical College First Affiliated Hospital

\section{Guodong Zhu}

Xi'an Jiaotong University Medical College First Affiliated Hospital

Jin Zeng

Xi'an Jiaotong University Medical College First Affiliated Hospital

Dapeng Wu ( $\nabla$ wudapeng1974@163.com )

Xi'an Jiaotong University Medical College First Affiliated Hospital

\section{Case report}

Keywords: eyelid, metastasis, renal cell carcinoma, review, therapy

Posted Date: March 17th, 2021

DOI: https://doi.org/10.21203/rs.3.rs-283304/v1

License: (c) This work is licensed under a Creative Commons Attribution 4.0 International License. Read Full License 


\section{Abstract}

Introduction: Renal clear cell carcinoma(ccRCC) accounts for about $85 \%$ of patients with renal carcinoma and is the most common pathological type of renal cancer. Renal clear cell carcinomas usually metastasize to the lungs, lymph nodes, liver, bones, and brain, with rare skin metastases, especially to the eyelids. In this study, we report the third current case of renal clear cell carcinoma with eyelid mass as its initial presentation.

Case presentation: In this study, we describe in detail the case of a 62-year-old male patient with clear cell carcinoma of the kidney whose first symptom was a mass of the right eyelid. The patient had no clinical manifestations other than eyelid mass before the diagnosis of renal clear cell carcinoma. After resection of eyelid mass, postoperative pathological and immunohistochemical studies showed clear cell carcinoma of the kidney. Subsequently, a computed tomography scan disclosed bilateral renal tumors, bilateral adrenal nodules, and nodules in the upper lobe of the left lung. At the time of writing, the patient was receiving sunitinib treatment and receiving regular outpatient follow-up.

Discussion and conclusion: Metastasis of renal carcinoma to the eye is rare, especially with an eyelid mass as the initial presentation. If they occur before the diagnosis of cancer or years after nephrectomy, the diagnosis of the tumor may be missed. In this study, we report the rare case and review reports of renal cell carcinoma metastasizing to the eye to raise our awareness of this rare phenomenon.

\section{Introduction}

Renal clear cell carcinoma (RCC) is the most common form of renal tumor, accounting for up to $85 \%$ of cases. Men are more common than women (1.7 to 1), and most are older, with an average age of 64[1, 2]. Renal cell carcinoma has a poor prognosis, with an overall 5-year survival rate of $74 \%$, a decrease to $53 \%$ in patients with local metastasis (stage III), and a 5year survival rate of less than 10\% (16-20 months) in patients with distant metastasis (stage IV)[3,4]. A puzzling feature of distant metastasis of renal cell carcinoma is the long incubation period between initial diagnosis and the onset of metastatic disease, and the maximum incubation period reported in existing cases exceeding 25 years. This feature makes it difficult to follow up RCC patients[5]. We reviewed reports of RCC metastases to the eye. These reported cases were initially suspected to be eye diseases such as uveal melanoma, sebaceous cysts, lachrymal mixed tumor and orbital hemangioma, but were subsequently histologically confirmed to be metastatic renal cell carcinoma. These rare eye metastases can have a variety of eye symptoms and can be ignored and delayed if they occur before the cancer is diagnosed or years after nephrectomy. In this study, we reported a clear cell carcinoma of the kidney with an eyelid mass as the first manifestation, and reviewed reports of RCC metastasis to the eye to improve our understanding of this rare phenomenon.

\section{Case Report}

A 62-year-old man was found to have a slow growth of upper eyelid nodules in his right eye one year ago. His vision, intraocular pressure, and fundus examination were all within the normal range, without skin ulcers, pigmentation, or tenderness (Fig. 1a). Plastic surgeons removed the eyelid tumor three months ago. Postoperative histopathological examination showed that the eyelid mass consisted of round and oval cell nests rich in hyaline cytoplasm, surrounded by abundant vascular network (Fig. 1c and d). The immunohistochemical characteristics of the tumor (Vim+, CD10+, CK+, pax$8+$, RCC+, P504S+) were consistent with the characteristics of RCC (Fig. 1e and f). Subsequently, a computed tomography (CT) scan revealed a circular soft tissue shadow of $83 \mathrm{~mm}$ and $13 \mathrm{~mm}$ in diameter at the lower pole of the left kidney and the lower pole of the right kidney, with uneven density. (Fig. 1b).In addition, positron emission and computer tomography (PET/CT) also revealed bilateral adrenal nodules and metastatic pulmonary nodules of $8 \mathrm{~mm}$ in the upper lobe of the left lung. According to the pathological stage (T4NxM1) and the patient's wishes, the patient finally chose the conservative treatment with the oral targeted drug sunitinib and monthly outpatient follow-up. This research was approved by the ethics

Page $2 / 9$ 
committee of The First Affiliated Hospital of Medical College of Xi'an Jiaotong University, and written informed consent was obtained from the relative of the patient.

\section{Discussion}

At present, there is no standardized treatment for renal carcinoma with eyelid metastasis. We consider that patients with renal carcinoma with eyelid metastasis should be actively treated, and patients with single eyelid metastasis without metastasis of other organs should be surgically removed. Due to the special biological characteristics of renal carcinoma cells, most renal carcinomas are not sensitive to chemotherapy and radiotherapy. Previous studys showed that the prognosis of patients with simple surgical resection and metastasis combined with postoperative radiotherapy, cytokines, and immunotherapy was not satisfactory. In the era of targeted therapy, several large retrospective studies have shown that, for patients with metastatic renal cancer who can withstand surgery, targeted therapy after tumor reduction nephrectomy has a better prognosis than simple targeted therapy[6, 7]. Besides, targeted drug combination therapy can be used as the second-line treatment for metastatic renal cancer. Following the FDA approval of sunitinib combined with everolimus for the second-line treatment based on this study in 2016, the current NCCN guidelines also recommend sunitinib combined with everolimus for the second-line treatment for patients with metastatic renal cancer[8]. The combination of targeted drugs and immune checkpoint inhibitors is also a trend in the treatment of metastatic renal cancer. Preclinical studies have shown that anti-angiogenic drugs can enhance the anti-tumor immune effect of the tumor microenvironment, and immune checkpoint inhibitors may induce a lasting response, so anti-angiogenic drugs combined with immune checkpoint inhibitors have a broad prospect for treatment strategies[9]. Therefore, for patients with single eyelid metastasis but no other metastasis, resection of primary renal carcinoma, metastasis, and combined targeted drug therapy may prolong the survival time and improve the quality of life of patients.

Distant metastases to renal clear cell carcinoma most frequently occur in the lung (45-50\%), bone (10-49\%), liver (14-20\%), and brain (2-16\%)[10]. It is unusual for RCC to metastasize to the eyelid with an eyelid mass as the first symptom. Although hematogenous spread and lymphatic metastasis are the most common routes of tumor metastasis to the eyelid, no tumor invasion of the tissues around the eye and no metastasis to the skin was observed in this patient, so it was difficult for our patient to distinguish which type of metastasis was present. It is not clear why patients with renal cancer develop metastases many years after the removal of the primary lesion. The metastasis is not necessarily related to tumor size, that is, sometimes the primary tumor is large but does not metastasize. Sometimes the tumor is small and asymptomatic but has distant metastases. The prognosis of renal cell carcinoma with multiple metastases has always been poor, and early detection of renal cell carcinoma may improve 5-year survival. Debraj Shome et al. reviewed 71 reported cases of RCC metastases to the eye from 1934 to 2004[11]. Here, we reviewed 35 cases of RCC metastases to the eyes reported in the English literature between 2004 and 2020 (Table 1)[5, 11-40]. These two studies include 107 cases with metastasis to the eyebrow ( 1 case, $0.93 \%)$, extraocular muscles (1 case, $0.93 \%)$, tear ducts ( 3 cases, $2.80 \%)$, retinal (3 cases, $2.80 \%)$, conjunctival (4 cases, 3.74\%), eyelid ( 5 cases, $4.70 \%$ ), ciliary body ( 6 cases, $5.61 \%$ ), iris (10 cases, 9.34\%), choroid ( 29 cases, $27.10 \%)$, orbital (39 cases, $36.44 \%$ ) and the other 6 cases intraocular metastatic RCC (5.61\%). Metastasis of renal cell carcinoma may occur many years after nephrectomy or maybe the first manifestation of the primary malignancy. It is associated with the latency between the initial diagnosis and metastatic presentation, which further increases the difficulty of diagnosis, so histopathological examination after the removal of the surface mass is necessary. The distant metastasis of renal cancer is often the first symptom, carefully looking for the primary foci only found in the kidney, thus it can be seen that the abnormal things in any part of the body, especially unknown sources, should think of the possibility of renal cancer metastasis.RCC metastases to the eye are rare, so urologists need to be aware of any recently discovered superficial masses during RCC follow-up.

\section{Conclusion}


There are only two other reports in the literature of eyelid metastatic renal cell carcinoma that are similar to the initial presentation of our case. A total of 13 cases $(36.11 \%)$ with eye symptoms as the first manifestation were listed in our review, and 23 cases (63.89\%) with eye metastases after diagnosis of renal cancer. Among the cases with ocular metastasis studied by Debraj Shome, MD et al., 39 cases (54.93\%) had no previous history of renal cell carcinoma and 32 cases (45.07\%) had a previous history of renal cell carcinoma. The reason for this difference may be the development and popularization of medical imaging, histopathology and immunohistochemistry. At present, there is no standard treatment for eye metastasis of renal clear cell carcinoma. Postoperative oral targeted drugs, targeted drugs combined with immune checkpoint inhibitors are used in the treatment of these diseases. Renal clear cell carcinoma metastases to the eye are rare and may occur many years after nephrectomy, or may be the first manifestation of primary malignancy. Once diagnosed, these diseases are usually advanced, so urologists should pay attention to them during RCC follow-up.

\section{Declarations}

\section{Acknowledgements}

None

\section{Funding}

None

\section{Conflict of interest}

None declared.

\section{Ethics approval and consent to participate}

Not applicable.

\section{Consent for publication}

Consent for the publication of individual patients was obtained from the patient.

\section{Availability of data and materials}

All data supporting the findings of this study are available within the article.

\section{Authors' contributions}

Qixiang Fang, Jin Zeng, and Dapeng Wu conceived the study. Wei Chen and Na Xie collected the clinical data. Na Xie, Wei Chen, and Guodong Zhu processed the data. Jin Zeng and Dapeng Wu reviewed the literature. Qlxiang Fang, Jin Zeng, and $\mathrm{Na}$ Xie drafted and revised the manuscript. Jin Zeng, Guodong Zhu, and Dapeng Wu contributed to the process of review. The authors read and approved the final manuscript.

\section{References}

1. Siegel R, Miller K, Jemal A. Cancer Statistics, 2017. CA: a cancer journal for clinicians. 2017;67(1):7-30.

2. Choueiri T, Motzer R. Systemic Therapy for Metastatic Renal-Cell Carcinoma. The New England journal of medicine. 2017;376(4):354-66.

3. Motzer R, Hutson T, Tomczak P, Michaelson M, Bukowski R, Oudard S, et al. Overall survival and updated results for sunitinib compared with interferon alfa in patients with metastatic renal cell carcinoma. Journal of clinical oncology : 
official journal of the American Society of Clinical Oncology. 2009;27(22):3584-90.

4. Motzer R, Mazumdar M, Bacik J, Berg W, Amsterdam A, Ferrara J. Survival and prognostic stratification of 670 patients with advanced renal cell carcinoma. Journal of clinical oncology : official journal of the American Society of Clinical Oncology. 1999;17(8):2530-40.

5. Bellerive $C$, Allaire G, Callejo S. A late onset of choroidal metastasis from renal cell carcinoma simulating melanoma. Canadian journal of ophthalmology Journal canadien d'ophtalmologie. 2017;52(3):e108-e10.

6. Conti S, Thomas I, Hagedorn J, Chung B, Chertow G, Wagner T, et al. Utilization of cytoreductive nephrectomy and patient survival in the targeted therapy era. International journal of cancer. 2014;134(9):2245-52.

7. Heng D, Wells J, Rini B, Beuselinck B, Lee J, Knox J, et al. Cytoreductive nephrectomy in patients with synchronous metastases from renal cell carcinoma: results from the International Metastatic Renal Cell Carcinoma Database Consortium. European urology. 2014;66(4):704-10.

8. Angulo J, Shapiro O. The Changing Therapeutic Landscape of Metastatic Renal Cancer. Cancers. 2019;11(9).

9. Bunt S, Yang L, Sinha P, Clements V, Leips J, Ostrand-Rosenberg S. Reduced inflammation in the tumor microenvironment delays the accumulation of myeloid-derived suppressor cells and limits tumor progression. Cancer research. 2007;67(20):10019-26.

10. Bianchi M, Sun M, Jeldres C, Shariat S, Trinh Q, Briganti A, et al. Distribution of metastatic sites in renal cell carcinoma: a population-based analysis. Annals of oncology : official journal of the European Society for Medical Oncology. 2012;23(4):973-80.

11. Shome D, Honavar S, Gupta P, Vemuganti G, Reddy P. Metastasis to the eye and orbit from renal cell carcinoma-a report of three cases and review of literature. Survey of ophthalmology. 2007;52(2):213-23.

12. Kuroki H, Oyama N, Koike H. [A Case of an Orbital Metastasectomy in a Renal Cell Carcinoma after Sunitinib Treatment : A Case Report]. Hinyokika kiyo Acta urologica Japonica. 2015;61(8):335-9.

13. Imai Y, Matsuura T, Hisakane A, Moritake J, Bando S, Yamada H, et al. [A Case of Renal Cell Carcinoma Choroidal Metastasis Diagnosed from Vision Disorders]. Hinyokika kiyo Acta urologica Japonica. 2019;65(2):33-7.

14. Ayres B, McClendon T, Demirci H. Cavitary Choroidal Metastasis from Clear Cell Renal Cell Carcinoma. Optometry and vision science : official publication of the American Academy of Optometry. 2017;94(8):851-3.

15. Komanski C, Rubino S, Meyer J, Greven C. Choroidal Melanoma Mimicker: A Case of Metastatic Clear-Cell Renal Cell Carcinoma. Ocular oncology and pathology. 2017;3(4):279-82.

16. Shoaib K, Haq I, Ali K, Mukhtar M, Nazir M. Choroidal metastasis from renal cell carcinoma presenting with cataract. Journal of the College of Physicians and Surgeons-Pakistan : JCPSP. 2008;18(6):380-1.

17. Kurashige Y, Otani A, Yoshimura N. Choroidal metastasis of renal cell carcinoma: a case report. Japanese journal of ophthalmology. 2010;54(1):111-2.

18. Wong M, Lee W, Halpern R, Frank J. Ciliary body metastasis from renal cell carcinoma successfully treated with intravitreal bevacizumab. American journal of ophthalmology case reports. 2017;6:61-3.

19. Marie-Louise J, Merle H, Donnio A, Ayeboua L, Jean-Charles A, Guyomarc'h J, et al. [Diagnosis of a clear cell renal carcinoma by biopsy of an iris metastasis associated with ocular hypertension in a black man from Martinique: Case report and literature review]. Journal francais d'ophtalmologie. 2015;38(10):e247-8.

20. Kurli M, Finger P, Schneider S, Tena L. Eyelid-sparing adjuvant radiation therapy for renal cell carcinoma. Ophthalmologica Journal international d'ophtalmologie International journal of ophthalmology Zeitschrift fur Augenheilkunde. 2006;220(3):198-200.

21. Priluck J, Grover S, Chalam K. Meridional lenticular astigmatism associated with bilateral concurrent uveal metastases in renal cell carcinoma. Clinical ophthalmology (Auckland, NZ). 2012;6:1839-41.

22. Jung J, Yoon S, Han D, Chi M. Metastatic renal cell carcinoma to the orbit and the ethmoid sinus. The Journal of craniofacial surgery. 2012;23(2):e136-8. 
23. Sharma K, Verma A, Rathi B, Kumar R, Kanaujia V. Metastatic tumor of orbit presenting as pulsatile proptosis. Annals of ophthalmology (Skokie, III). 2006;38(1):69-72.

24. Pompeu A, Arap S, Silva M, Monteiro D. Ocular metastasis as first presentation of renal cell carcinoma: report of 2 cases. Clinics (Sao Paulo, Brazil). 2005;60(1):75-8.

25. Rai R, Jakobiec F, Fay A. Ocular Metastatic Renal Carcinoma Presenting With Proptosis. Ophthalmic plastic and reconstructive surgery. 2015;31(4):e100-8.

26. Preechawai P, Amrith S, Yip C, Goh K. Orbital metastasis of renal cell carcinoma masquerading as cysticercosis. Orbit (Amsterdam, Netherlands). 2008;27(5):370-3.

27. Evgeniou E, Menon K, Jones G, Whittet $H$, Williams W. Renal cell carcinoma metastasis to the paranasal sinuses and orbit. BMJ case reports. 2012;2012.

28. Essadi I, Lalya I, Kriet M, El Omrani A, Belbaraka R, Khouchani M. Successful management of retinal metastasis from renal cancer with everolimus in a monophthalmic patient: a case report. Journal of medical case reports. 2017;11(1):340.

29. Greco F, Sabatino L, Sabatino F, Casale M, Quattrocchi C, Zobel B. Unilateral Blepharoptosis from Renal Cell Carcinoma. Journal of kidney cancer and VHL. 2016;3(3):11-5.

30. Mancini V, Battaglia M, Lucarelli G, Di Lorenzo V, Ditonno P, Bettocchi C, et al. Unusual solitary metastasis of the ciliary body in renal cell carcinoma. International journal of urology : official journal of the Japanese Urological Association. 2008;15(4):363-5.

31. Selby L, Stiefel H, Skalet A, Cardenal M, Bhavsar K, Winges K. Vision Loss from Choroidal and Pituitary Metastases Secondary to Renal Cell Carcinoma: A Case Report. Neuro-ophthalmology (Aeolus Press). 2018;42(6):391-8.

32. Castro Navarro J, Señaris González A, González Rodríguez C, Rozas Reyes P, González Castaño C. [Choroidal metastasis from renal cell carcinoma]. Archivos de la Sociedad Espanola de Oftalmologia. 2004;79(12):633-6.

33. Cabrera-Beyrouti R, Campos-Mollo E, Rico-Santos E, Jiménez-Rodríguez D, Lledó-Riquelme M, Vierna-García J. Eyelid metastasis as first presentation of renal cell carcinoma. Archivos de la Sociedad Espanola de Oftalmologia. 2017;92(11):547-51.

34. Gonzalez F, Abalo-Lojo J, Suarez-Peñaranda J, Caneiro-Gómez J. Eyelid metastasis as the initial presentation of a renal cell carcinoma. Urology. 2015;85(5):e35-e6.

35. Vozmediano-Serrano M, Toledano-Fernández N, Fdez-Aceñero M, Gil-Díez J, García-Saenz S. Lacrimal sac metastases from renal cell carcinoma. Orbit (Amsterdam, Netherlands). 2006;25(3):249-51.

36. Coloma-González I, Ceriotto A, Amezquita-García E, Flores-Preciado J, Salcedo-Casillas G. Orbital pulsatile metastasis as initial presenting sign of metastatic clear cell renal carcinoma. Archivos de la Sociedad Espanola de Oftalmologia. 2014;89(12):500-3.

37. Hainăroşie R, Anghelina F, Ioniţă I, Zoican O, Pietroşanu C, Piţuru S, et al. Rare metastasis of renal carcinoma in the frontoethmoid-orbital region - case report and review of the literature. Romanian journal of morphology and embryology = Revue roumaine de morphologie et embryologie. 2017;58(4):1497-504.

38. Lapp T, Mittelviefhaus H, Werner M, Auw-Hädrich C. Severe bleeding eyelid after trivial trauma: conjunctival metastasis of a renal cell carcinoma. Graefe's archive for clinical and experimental ophthalmology = Albrecht von Graefes Archiv fur klinische und experimentelle Ophthalmologie. 2012;250(11):1705-6.

39. Hart R, Luthert P, Rose G. Renal cell carcinoma metastasis masquerading as recurrent orbital haematoma. Orbit (Amsterdam, Netherlands). 2005;24(4):281-4.

40. Dave V, Shah A, Menon S. An unusual case of metastatic choroidal deposits of renal cell carcinoma presenting with loss of vision. Journal of postgraduate medicine. 2020;66(4):220-1.

\section{Table}


Table 1

Eye metastasis of RCC reported in English literature (2004-2020)

\begin{tabular}{|c|c|c|c|c|c|c|c|}
\hline $\begin{array}{l}\text { Metastatic } \\
\text { site }\end{array}$ & First author & Year & $\begin{array}{l}\text { Age } \\
\text { (years)/ } \\
\text { sex }\end{array}$ & Site & $\begin{array}{l}\text { Before / } \\
\text { After the } \\
\text { diagnosis } \\
\text { of kidney } \\
\text { cancer }\end{array}$ & Other Metastatic site & $\begin{array}{l}\text { The treatment of } \\
\text { metastatic tumor }\end{array}$ \\
\hline \multicolumn{8}{|l|}{ Eyelid } \\
\hline & Kurli, $\mathrm{M}^{20}$ & 2006 & $63 / M$ & NA & After & Lung & $\begin{array}{l}\text { Resection and } \\
\text { systemic } \\
\text { chemotherapy }\end{array}$ \\
\hline & $\begin{array}{l}\text { Gonzalez, } \\
\mathrm{F}^{34}\end{array}$ & 2015 & $77 / M$ & Right & Before & Lung & NA \\
\hline & $\begin{array}{l}\text { Cabrera- } \\
\text { Beyrouti, } \mathrm{R}^{33}\end{array}$ & 2017 & $87 / M$ & Bilateral & Before & Lung & Palliative therapy \\
\hline & Our study & & $62 / M$ & Bilateral & Before & $\begin{array}{l}\text { Lung and adrenal } \\
\text { gland }\end{array}$ & $\begin{array}{l}\text { Resection and } \\
\text { radiotherapy }\end{array}$ \\
\hline \multicolumn{8}{|l|}{ Conjunctiva } \\
\hline & $\begin{array}{l}\text { Pompeu, } \\
\mathrm{AC}^{24}\end{array}$ & 2005 & $59 / M$ & Left & Before & $\begin{array}{l}\text { Inferior rectus } \\
\text { muscle }\end{array}$ & Resection \\
\hline & & 2005 & $72 / \mathrm{M}$ & Right & Before & Lymph nodes & Resection \\
\hline & Lapp, $\mathrm{T}^{38}$ & 2012 & $70 / F$ & Left & After & Lung and brain & $\begin{array}{l}\text { Resection and } \\
\text { Sunitinib }\end{array}$ \\
\hline \multicolumn{8}{|l|}{ Iris } \\
\hline & Shome, $D^{11}$ & 2007 & $67 / M$ & Right & After & $\begin{array}{l}\text { Lung, bone, and } \\
\text { lymph nodes }\end{array}$ & $\begin{array}{l}\text { Interferon- } a \text { and } \\
\text { radiotherapy }\end{array}$ \\
\hline & $\begin{array}{l}\text { Marie- } \\
\text { Louise, } J^{19}\end{array}$ & 2015 & NA & NA & After & Cerebellum & NA \\
\hline \multicolumn{8}{|l|}{ Tear gland } \\
\hline & $\begin{array}{l}\text { Vozmediano- } \\
\text { Serrano, } \\
\text { MT }^{35}\end{array}$ & 2006 & $56 / F$ & Right & After & NO & Resection \\
\hline \multicolumn{8}{|l|}{ Ciliary body } \\
\hline & Mancini, $V^{30}$ & 2008 & $42 / \mathrm{M}$ & Right & After & Lung and bulbar & $\begin{array}{l}\text { Resection and } \\
\text { interleukin-2 }\end{array}$ \\
\hline & Wong, $\mathrm{M}^{18}$ & 2017 & $70 / \mathrm{M}$ & NA & After & $\begin{array}{l}\text { Lung,bone, } \\
\text { mediastinum,adrenal } \\
\text { glands, and lymph } \\
\text { nodes. }\end{array}$ & Bevacizumab \\
\hline \multicolumn{8}{|l|}{ Retina } \\
\hline & Priluck, JC ${ }^{21}$ & 2012 & $63 / M$ & NA & After & Uveal & NA \\
\hline & Rai, $R^{25}$ & 2015 & $73 / F$ & Bilateral & After & Orbit & Resection \\
\hline
\end{tabular}




\begin{tabular}{|c|c|c|c|c|c|c|c|}
\hline $\begin{array}{l}\text { Metastatic } \\
\text { site }\end{array}$ & First author & Year & $\begin{array}{l}\text { Age } \\
\text { (years)/ } \\
\text { sex }\end{array}$ & Site & $\begin{array}{l}\text { Before / } \\
\text { After the } \\
\text { diagnosis } \\
\text { of kidney } \\
\text { cancer }\end{array}$ & Other Metastatic site & $\begin{array}{l}\text { The treatment of } \\
\text { metastatic tumor }\end{array}$ \\
\hline & Essadi, $\left.\right|^{28}$ & 2017 & $62 / \mathrm{M}$ & NA & After & Lung & Everolimus \\
\hline \multicolumn{8}{|l|}{ Choroid } \\
\hline & $\begin{array}{l}\text { Castro } \\
\text { Navarro, J32 }\end{array}$ & 2004 & $52 / M$ & Right & After & Lung & Resection \\
\hline & Shoaib, KK ${ }^{16}$ & 2008 & $71 / \mathrm{M}$ & Left & After & vitreous body & Resection \\
\hline & $\begin{array}{l}\text { Kurashige, } \\
Y^{17}\end{array}$ & 2010 & $58 / \mathrm{M}$ & Left & After & Lung & Resection \\
\hline & $\begin{array}{l}\text { Komanski, } \\
\mathrm{CB}^{15}\end{array}$ & 2017 & 73/M & Right & After & NO & $\begin{array}{l}\text { Resection and } \\
\text { radiotherapy }\end{array}$ \\
\hline & Ayres, $B^{14}$ & 2017 & $81 / M$ & NA & After & Lung and ribs, & $\begin{array}{l}\text { Brachytherapy and } \\
\text { Sunitinib }\end{array}$ \\
\hline & Bellerive, $C^{5}$ & 2017 & 73/M & NA & After & Lung & $\begin{array}{l}\text { Resection and } \\
\text { Sunitinib }\end{array}$ \\
\hline & Selby, LD 31 & 2018 & $62 / M$ & NA & After & $\begin{array}{l}\text { Lung, stomach, } \\
\text { bone, adrenal gland } \\
\text { and pituitary gland }\end{array}$ & $\begin{array}{l}\text { Resection,sunitinib } \\
\text { and radiotherapy }\end{array}$ \\
\hline & Imai, $Y^{13}$ & 2019 & $69 / M$ & Left & Before & $\begin{array}{l}\text { Lung and lymph } \\
\text { nodes }\end{array}$ & $\begin{array}{l}\text { Pazopanib and } \\
\text { radiotherapy }\end{array}$ \\
\hline & Dave, $\mathrm{V}^{40}$ & 2020 & 71/M & Right & After & Lung & Sunitinib \\
\hline \multicolumn{8}{|l|}{ Orbit } \\
\hline & Hart, $\mathrm{RH}^{39}$ & 2005 & $70 / M$ & NA & After & NA & Resection \\
\hline & $\begin{array}{l}\text { Pompeu, } \\
\mathrm{AC}^{24}\end{array}$ & 2005 & $59 / \mathrm{M}$ & Left & Before & $\begin{array}{l}\text { Lung and lymph } \\
\text { nodes }\end{array}$ & Resection \\
\hline & Shome, $\mathrm{D}^{11}$ & 2006 & $58 / \mathrm{M}$ & Right & Before & NA & Radiotherapy \\
\hline & & 2006 & $23 / F$ & Right & After & Lymph nodes & Palliative therapy \\
\hline & Sharma, $\mathrm{K}^{23}$ & 2006 & $69 / M$ & Left & Before & NA & Radiotherapy \\
\hline & $\begin{array}{l}\text { Preechawai, } \\
\mathrm{P}^{26}\end{array}$ & 2008 & $48 / \mathrm{M}$ & Right & Before & $\begin{array}{l}\text { Lung, bone and } \\
\text { lymph nodes }\end{array}$ & Palliative therapy \\
\hline & $\begin{array}{l}\text { Evgeniou, } \\
\mathrm{E}^{27}\end{array}$ & 2012 & $74 / M$ & NA & After & $\begin{array}{l}\text { Paranasal sinus and } \\
\text { thymic fat }\end{array}$ & $\begin{array}{l}\text { Palliative } \\
\text { radiotherapy }\end{array}$ \\
\hline & Jung,JW22 & 2012 & $50 / M$ & Right & After & Ethmoid sinus & $\begin{array}{l}\text { Resection and } \\
\text { Interferon-a }\end{array}$ \\
\hline & $\begin{array}{l}\text { Coloma- } \\
\text { González, I } 36\end{array}$ & 2014 & $53 / M$ & NA & After & NO & Interferon-a \\
\hline
\end{tabular}




\begin{tabular}{|c|c|c|c|c|c|c|c|}
\hline $\begin{array}{l}\text { Metastatic } \\
\text { site }\end{array}$ & First author & Year & $\begin{array}{l}\text { Age } \\
\text { (years)/ } \\
\text { sex }\end{array}$ & Site & $\begin{array}{l}\text { Before / } \\
\text { After the } \\
\text { diagnosis } \\
\text { of kidney } \\
\text { cancer }\end{array}$ & Other Metastatic site & $\begin{array}{l}\text { The treatment of } \\
\text { metastatic tumor }\end{array}$ \\
\hline & Kuroki, $\mathrm{H}^{12}$ & 2015 & $81 / \mathrm{M}$ & NA & After & NA & $\begin{array}{l}\text { Resection and } \\
\text { Sunitinib }\end{array}$ \\
\hline & Greco, $F^{29}$ & 2016 & $47 / \mathrm{M}$ & Left & Before & lymph nodes & NA \\
\hline & $\begin{array}{l}\text { Hainăroşie, } \\
\mathrm{R}^{37}\end{array}$ & 2017 & $60 / \mathrm{M}$ & Right & Before & $\begin{array}{l}\text { Frontal sinus and } \\
\text { ethmoid sinus }\end{array}$ & Resection \\
\hline
\end{tabular}

Abbreviations: F, female; M, male; NA, not

\section{Figures}

Figure 1

(a)A color photograph of the lower right eyelid shows a mass without ulceration or pigmentation. (b)A computed tomography (CT) scan revealed a circular soft tissue shadow at the lower pole of the left kidney and the lower pole of the

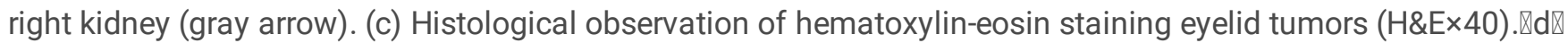
Postoperative histopathological examination revealed that the eyelid mass was composed of cells rich in hyaline cytoplasm with nuclear heterogeneity (H\&Ex400). (e) Vimentin immunostaining showing strong and diffuse positive stain.(f) PAX-8 immunostain showing strong nuclear positivity, and suggesting the renal origin of the neoplasm. $(\times 400$ [e and f]) 